\title{
Nucleotide excision repair pathway assessment in DNA exposed to low-intensity red and infrared lasers
}

\author{
A.S. Fonseca ${ }^{1,2,3}$, V.M.A. Campos ${ }^{1}$, L.A.G. Magalhães ${ }^{1}$ and F. Paoli ${ }^{4}$ \\ ${ }^{1}$ Laboratório de Ciências Radiológicas, Departamento de Biofísica e Biometria, Instituto de Biologia Roberto Alcântara Gomes, \\ Rio de Janeiro, RJ, Brasil \\ ${ }^{2}$ Departamento de Ciências Fisiológicas, Instituto Biomédico, Universidade Federal do Estado do Rio de Janeiro, \\ Rio de Janeiro, RJ, Brasil \\ ${ }^{3}$ Centro de Ciências da Saúde, Centro Universitário Serra dos Órgãos, Teresópolis, RJ, Brasil \\ ${ }^{4}$ Departamento de Morfologia, Instituto de Ciências Biológicas, Universidade Federal de Juiz de Fora, Juiz de Fora, MG, Brasil
}

\begin{abstract}
Low-intensity lasers are used for prevention and management of oral mucositis induced by anticancer therapy, but the effectiveness of treatment depends on the genetic characteristics of affected cells. This study evaluated the survival and induction of filamentation of Escherichia coli cells deficient in the nucleotide excision repair pathway, and the action of $\mathrm{T}_{4}$ endonuclease $\mathrm{V}$ on plasmid DNA exposed to low-intensity red and near-infrared laser light. Cultures of wild-type (strain AB1157) E. coli and strain AB1886 (deficient in uvrA protein) were exposed to red $(660 \mathrm{~nm})$ and infrared $(808 \mathrm{~nm})$ lasers at various fluences, powers and emission modes to study bacterial survival and filamentation. Also, plasmid DNA was exposed to laser light to study DNA lesions produced in vitro by $\mathrm{T}_{4}$ endonuclease $\mathrm{V}$. Low-intensity lasers: $i$ ) had no effect on survival of wild-type $E$. coli but decreased the survival of uvrA protein-deficient cells, ii) induced bacterial filamentation, iii) did not alter the electrophoretic profile of plasmids in agarose gels, and $\mathrm{iv}$ ) did not alter the electrophoretic profile of plasmids incubated with $\mathrm{T}_{4}$ endonuclease $\mathrm{V}$. These results increase our understanding of the effects of laser light on cells with various genetic characteristics, such as xeroderma pigmentosum cells deficient in nucleotide excision pathway activity in patients with mucositis treated by low-intensity lasers.
\end{abstract}

Key words: DNA; Enzyme; Escherichia coli; Filamentation; Laser

\section{Introduction}

Oral mucositis is a common inflammatory process caused by chemotherapy and radiotherapy against head and neck cancers (1). It can have severe effects on patient quality of life, including secondary infections, difficulty in swallowing and chewing, soreness, edema, erythema, ulcerations, bleeding, and pain during oncologic treatment (2). The strategies used to prevent and treat mucositis include basic oral care protocols, anti-inflammatory therapy, biologic response modifiers, cytoprotectants and cryotherapy (3). Use of low-intensity lasers to treat mucositis has gained in importance, and has been successful in prevention and management of oral mucositis induced by anticancer therapy (4).

Because of their biostimulatory effect, red and nearinfrared lasers, which are nonthermal and nondestructive at low intensity, are widely used in a variety of health care settings for mucositis and other soft tissue repair. Biostimulation, an increase in cell metabolism following exposure to laser light, leads to alterations of biochemical reactions and changes in a number of cellular responses (5-7). The responses to low-intensity laser irradiation are related to alterations of the regenerative potential of tissues, neovascularization, and formation of scar tissue $(8,9)$. Cytochrome $\mathrm{C}$ in mammalian cells and cytochrome $\mathrm{BD}$ in bacterial cells are considered to be chromophores involved in the absorption of red and near-infrared laser light $(10,11)$. A primary photosignal stimulated by absorption of laser energy is subsequently transduced to an amplified signal in the cells (10). Highly reactive chemical compounds are generated in these transduction-signal pathways, and they have potential photobiological side effects (5). In fact, it has been suggested that laser radiation induces free radical production $(5,12,13)$, which could produce an imbalance between oxidant and antioxidant concentration. An excess of free radicals, by reacting with biomolecules, could cause modifications of cellular function, leading to undesired effects. The nature of laser-induced side effects is still in dispute, although

Correspondence: A.S. Fonseca: <adnfonseca@ig.com.br>.

Received November 30, 2014. Accepted March 17, 2015. First published online July 10, 2015. 
there are data about DNA damage after laser exposure in eukaryotic (13-15) and prokaryotic cells $(16,17)$. Moreover, previous studies have demonstrated that red and near-infrared lasers decrease survival of $E$. coli cells deficient in base excision repair, a pathway involved in repair of oxidative DNA lesions, and induce the filamentation phenotype more frequently than in wild type $E$. coli cells (18-20). While the controversies about laser-induced DNA lesions by free radicals have not been resolved, it is interesting to evaluate whether other DNA repair pathways are involved in cellular responses to lowintensity lasers.

Nucleotide excision repair is an important DNA repair pathway involving excision of pyrimidine dimers and other bulky lesions induced in DNA by ultraviolet radiation. In $E$. coli, this pathway comprises three proteins (uvrA, uvrB, and uvrC) that have recognition, cleavage, and endonuclease functions. Compared with "excisionrepair proficient" wild-type cells, $E$. coli cells deficient in one or more of these genes are more sensitive to ultraviolet radiation, and were used in early studies to simulate xeroderma pigmentosum cell responses to solar ultraviolet radiation (21). Expression of the uvr gene comprises part of a response set dominated by the SOS function in bacterial cells exposed to hazardous physical and chemical agents (22). In addition to uvr gene expression, filamentation, anomalous bacterial growth with cell elongation in the absence of septa formation, occurs in response to ultraviolet radiation (23). This morphological abnormality has been used to evaluate effects of environmental agents on the integrity of DNA in bacterial cells (24).

With the increasing use of low-intensity lasers for treating various diseases, possible adverse effects on DNA must be considered. This is particularly important in the case of laser-based treatment of oral cavity disease, where the occurrence of radiation-induced mucositis, a potential side effect, has not been clearly documented or evaluated. This study evaluated survival and filamentation induction in $E$. coli cells deficient in the nucleotide excision repair pathway, and the action of T4 endonuclease $V$ on plasmid DNA exposed to low-intensity red and nearinfrared laser light. Various laser fluences, powers, and frequencies were selected from those described in the laser device manual.

\section{Material and Methods}

\section{Low-intensity red and near-infrared lasers and chemical reagents}

A therapeutic low-intensity red (InGaAIP) and nearinfrared (GaAlAs) laser (100 mW; Photon Lase III), with emissions of 660 and $808 \mathrm{~nm}$, was purchased from D.M.C Equipamentos Ltda. (Brazil). Ethidium bromide, xylene cyanol, bromophenol blue, glycerol, agarose, tris(hydroxymethyl)aminomethane (tris), and ethylenediamine tetraacetic acid (EDTA) were from Merck (USA). Sodium chloride $(\mathrm{NaCl})$, acetic acid, and sodium hydroxide $(\mathrm{NaOH})$ were from Vetec (Brazil). DNA repair enzyme from $E$. coli ( $T_{4}$ endonuclease $V$ ) was from New England Biolabs (USA).

\section{Survival of $E$. coli cells}

Cultures of E. coli AB1157 (wild-type) and AB1886 (uvrA deficient) in the exponential growth phase $\left(10^{8}\right.$ cells $\left./ \mathrm{mL}, 2-3 \mathrm{~h}, 37^{\circ} \mathrm{C}\right)$ were grown from stocks in the stationary growth phase. The cells were collected by centrifugation $(700 \mathrm{~g}, 15 \mathrm{~min})$, washed twice in saline $(0.9 \% \mathrm{NaCl})$, and resuspended in saline. Aliquots $(20 \mu \mathrm{L}$, $n=5$, for each fluence, power and emission mode) of bacterial suspensions $\left(10^{8}\right.$ cells $\left./ \mathrm{mL}\right)$ were exposed, at room temperature and under white light (fluorescent lamps), to low-intensity red and near-infrared laser light $\left(0.00785 \mathrm{~cm}^{2}\right.$ beam diameter) at various fluences $(25,50$, and $100 \mathrm{~J} / \mathrm{cm}^{2}$, corresponding to $0.7,1.5$, and $2.8 \mathrm{~J}$, respectively), and powers $(30,50$, and $100 \mathrm{~mW})$ in continuous wave and pulsed emission modes (10, 30, and 100 pulses/s). The laser source was positioned very close to the surface of the bacterial suspension, which was covered by the beam. The tissue exposure time was automatically adjusted by the laser device as a function of power and fluence (e.g., 7, 14, and $28 \mathrm{~s}$ for 25, 50, and $100 \mathrm{~J} / \mathrm{cm}^{2}$, respectively). Bacterial suspensions not exposed to lasers were used as controls. Bacterial suspensions were diluted in saline, plated onto Petri dishes containing solidified rich medium (Luria-Bertani, $1.5 \%$ agar). Colonies that formed following overnight incubation at $37^{\circ} \mathrm{C}$ were counted, and the survival fractions were calculated (25). Experiments were performed in triplicate, and results are reported as the mean of three independent assays.

\section{In vitro DNA repair enzyme activity on plasmid DNA}

$\mathrm{T}_{4}$ endonuclease $\mathrm{V}$ from $E$. coli was used in an in vitro DNA repair assay to evaluate the effect of low-intensity red and infrared laser light. Aliquots of plasmid DNA were exposed, at room temperature and in the light, to lowintensity red and infrared lasers as described in the bacterial survival assay. Immediately afterward, plasmids (approximately $200 \mathrm{ng}$ ) were mixed with enzyme buffer (2 units) and incubated $\left(37^{\circ} \mathrm{C}, 30 \mathrm{~min}\right)$. Each sample was then mixed with loading buffer $(0.25 \%$ xylene cyanol, $0.25 \%$ bromophenol blue, and $25 \%$ glycerol in water) and applied onto a horizontal $0.8 \%$ agarose gel electrophoresis chamber in tris-acetate-EDTA buffer $(40 \mathrm{mM}$ tris, $20 \mathrm{mM}$ acetic acid, $1 \mathrm{mM}$ EDTA, pH 8.0, $7 \mathrm{~V} / \mathrm{cm})$. Gels were stained with ethidium bromide $(0.5 \mu \mathrm{g} / \mathrm{mL})$, and the plasmid forms were viewed under fluorescence using an ultraviolet transillumination system. The assay was repeated at least three times. Digital images of the gels and plasmid forms were analyzed semiquantitatively using the ImageJ for Windows software (http://rsb.info.nih.gov/ij/ index.html). 


\section{Bacterial filamentation assay and morphological measurements}

Exponential growth phase cultures of $E$. coli strains AB1157 and AB1886 ( $10^{8}$ cells $\left./ \mathrm{mL}\right)$ were grown and exposed to low-intensity red and infrared laser light as described in the bacterial survival assay. Bacterial suspensions not exposed to laser light were used as controls. Immediately after laser exposure, aliquots $(10 \mu \mathrm{L})$ were spread onto microscopic slides and Gramstained (26). Bacterial cells were visualized with a light microscope (Carl Zeiss, Germany) equipped with an Aplan $40 \times$ objective, 0.90 condenser and $100 \mathrm{~W}$ halogen lamp. The images were captured with an AxioCam HRc Sony $12 \mathrm{M}$ color microscopy camera (Carl Zeiss), using the Zeiss Axiovision software (http://www.zeiss.com/ microscopy/en_us/products/microscope-software/axiovision-for-biology.html). The images were analyzed using the Image-Pro Plus 6.0 software for Windows XP (MediaCybernetics, USA) to determine the percentage of bacterial filamentation. A bacterial filament was considered to have an area 2.5 times larger than the mean bacterial cell area. Experiments were carried out in duplicate, and the results are reported as the means of three independent assays.

\section{Statistical analysis}

Data are reported as means $\pm S D$ of the bacterial survival fractions, plasmid forms, and the percentages, area, and perimeter of bacterial filaments. One-way analysis of variance (ANOVA) was performed to determine the significance of differences in the reported results, followed by the Bonferroni post-test, with $\mathrm{P}<0.05$ as the significance level. The InStat Graphpad software (GraphPad InStat for Windows XP, USA) was used to perform the statistical analysis.

\section{Results}

\section{Survival of $E$. coli cultures exposed to red and infrared lasers}

Table 1 shows the survival fractions of $E$. coli AB1157 and AB1886 cultures exposed to low-intensity red and infrared lasers at various fluences. No significant effect $(P>0.05)$ on survival was observed following irradiation of E. coli AB1157 cultures with red or infrared lasers. However, survival fractions of AB1886 cultures exposed to the red laser at the highest fluence $\left(100 \mathrm{~J} / \mathrm{cm}^{2}\right)$ and to the infrared laser at all fluences used were significantly decreased $(P<0.05)$.

To ascertain whether the laser beam power had an effect on laser-induced biological effects, survival was determined in E. coli AB1157 and AB1886 cultures exposed to red and infrared lasers at increasing powers, with the highest fluence being $100 \mathrm{~J} / \mathrm{cm}^{2}$ (Table 1). The survival fraction was significantly greater in E. coli AB1157 cultures exposed to both red and infrared lasers at the lowest power $(30 \mathrm{~mW})$ than it was in cultures exposed at the highest power $(100 \mathrm{~mW}, \mathrm{P}<0.05)$. On the other hand, the survival fraction in $E$. coli $A B 1886$ cultures was significantly decreased only in those exposed to the infrared laser at $100 \mathrm{~mW}(\mathrm{P}<0.05)$.

The emission mode (continuous wave and pulsed laser light) was also evaluated in this study. E. coli cultures were exposed to red and infrared lasers in the continuous

Table 1. Survival fractions of $E$. coli cultures exposed to red and infrared lasers at different fluences, powers, and emission modes.

\begin{tabular}{|c|c|c|c|c|}
\hline & \multicolumn{2}{|c|}{ AB1157 } & \multicolumn{2}{|c|}{ AB1886 } \\
\hline & Red & Infrared & Red & Infrared \\
\hline \multicolumn{5}{|c|}{ Fluence $\left(\mathrm{J} / \mathrm{cm}^{2}\right)$} \\
\hline Control & $1.0 \pm 0.12$ & $1.0 \pm 0.12$ & $1.0 \pm 0.11$ & $1.0 \pm 0.11$ \\
\hline 25 & $0.9 \pm 0.31$ & $1.0 \pm 0.28$ & $0.9 \pm 0.10$ & $0.7 \pm 0.21^{*}$ \\
\hline 50 & $1.0 \pm 0.39$ & $1.1 \pm 0.31$ & $1.0 \pm 0.05$ & $0.7 \pm 0.17^{*}$ \\
\hline 100 & $1.1 \pm 0.18$ & $1.0 \pm 0.26$ & $0.7 \pm 0.08^{*}$ & $0.6 \pm 0.10^{*}$ \\
\hline \multicolumn{5}{|l|}{ Power (mW) } \\
\hline 30 & $1.4 \pm 0.12^{*}$ & $1.7 \pm 0.41^{*}$ & $0.8 \pm 0.13^{*}$ & $0.9 \pm 0.12$ \\
\hline 50 & $1.2 \pm 0.19$ & $1.3 \pm 0.21$ & $0.7 \pm 0.15^{\star}$ & $0.9 \pm 0.10$ \\
\hline 100 & $1.1 \pm 0.18$ & $1.0 \pm 0.26$ & $0.7 \pm 0.08^{*}$ & $0.6 \pm 0.10^{*}$ \\
\hline \multicolumn{5}{|c|}{ Frequency (pps) } \\
\hline Continuous & $1.1 \pm 0.18$ & $1.0 \pm 0.26$ & $0.7 \pm 0.08^{*}$ & $0.6 \pm 0.10^{*}$ \\
\hline 10 & $1.0 \pm 0.16$ & $1.1 \pm 0.24$ & $1.1 \pm 0.14$ & $1.1 \pm 0.14$ \\
\hline 100 & $0.9 \pm 0.09$ & $0.9 \pm 0.10$ & $1.0 \pm 0.16$ & $1.0 \pm 0.21$ \\
\hline
\end{tabular}

Data are reported as the means $\pm S D$. pps: pulses per second. ${ }^{*} P<0.05$ vs control group not exposed to lasers (ANOVA). 

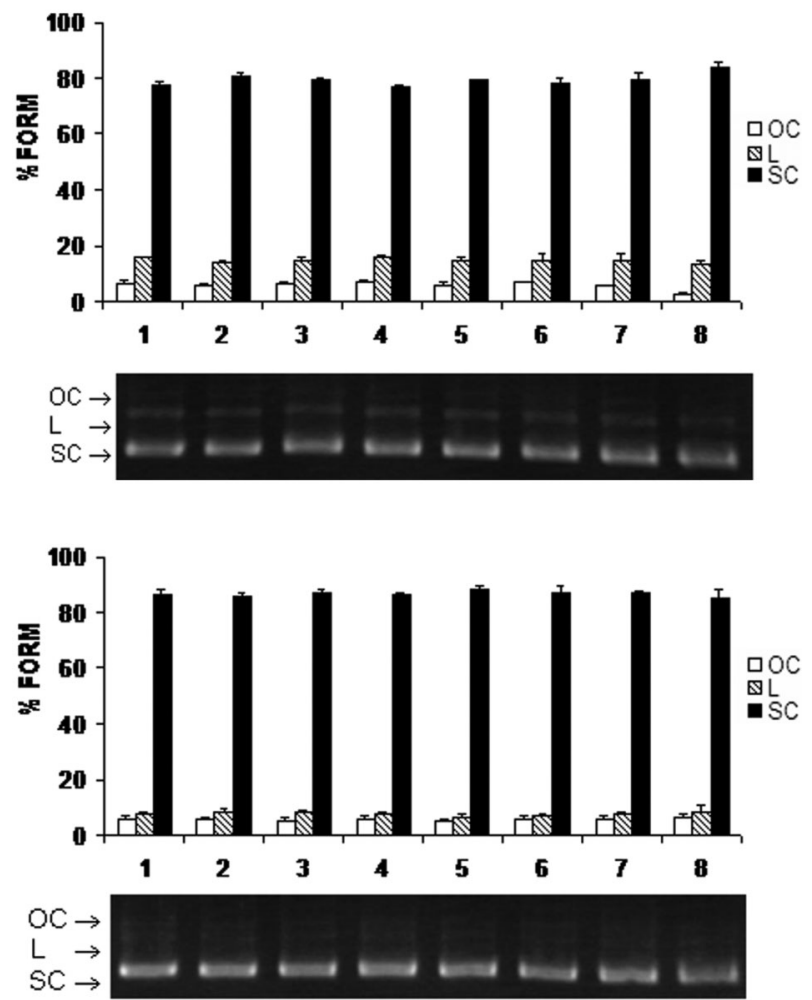

Figure 1. Percentages of bacterial plasmid forms and photographs of agarose gels after electrophoresis of plasmid pUC19 exposed to red lasers (top) and to infrared lasers (bottom), at $100 \mathrm{~mW}$ in continuous wave emission mode, and incubated with T4 endonuclease V. Top: lane 1, pUC19; lane 2, pUC19+T4 endonuclease $\mathrm{V}$; lane 3 , pUC19+red laser $25 \mathrm{~J} / \mathrm{cm}^{2}$; lane 4 , pUC19+ red laser $25 \mathrm{~J} / \mathrm{cm}^{2}+\mathrm{T} 4$ endonuclease $\mathrm{V}$; lane 5 , pUC19 + red laser $50 \mathrm{~J} / \mathrm{cm}^{2}$; lane 6 , pUC19+red laser $50 \mathrm{~J} / \mathrm{cm}^{2}+\mathrm{T} 4$ endonuclease V; lane 7 , pUC19+red laser $100 \mathrm{~J} / \mathrm{cm}^{2}$; lane 8 , pUC19+ red laser $100 \mathrm{~J} / \mathrm{cm}^{2}+\mathrm{T} 4$ endonuclease V. Bottom: lane 1, pUC19; lane 2, pUC19+ T4 endonuclease V; lane 3, pUC19 + infrared laser $25 \mathrm{~J} / \mathrm{cm}^{2}$; lane 4, pUC19+infrared laser 25 $\mathrm{J} / \mathrm{cm}^{2}+\mathrm{T} 4$ endonuclease $\mathrm{V}$; lane 5 , pUC19+infrared laser 50 $\mathrm{J} / \mathrm{cm}^{2}$; lane 6, pUC19+infrared laser $50 \mathrm{~J} / \mathrm{cm}^{2}+\mathrm{T} 4$ endonuclease V; lane 7, pUC19+infrared laser $100 \mathrm{~J} / \mathrm{cm}^{2}$; lane 8 , pUC19+ infrared laser $100 \mathrm{~J} / \mathrm{cm}^{2}+\mathrm{T} 4$ endonuclease V. Data are reported as the means $\pm S D$ for $n=3$ independent experiments. OC: open circle, L: linear, SC: supercoiled.

wave and pulsed emission (at 10 and $100 \mathrm{pps}$ ) modes at the highest fluence $\left(100 \mathrm{~J} / \mathrm{cm}^{2}\right)$ and power $(100 \mathrm{~mW})$, and the survival fractions were evaluated (Table 1). Survival of E. coli AB1157 was not dependent on the laser emission mode; no significant $(P>0.05)$ differences in survival fraction were observed. However, survival of exposed E. coli AB1886 cultures was dependent on the emission mode. The continuous wave mode caused a significant $(P<0.05)$ decrease of the survival fraction, but the pulsed mode did not cause significant $(P>0.05)$ alterations of bacterial survival in response to either red or infrared laser emissions.
DNA repair enzyme activity on plasmid DNA exposed to low-intensity red and infrared lasers

Figure 1 shows photographs of agarose gels and graphs of the percentages of bacterial plasmid forms quantified by electrophoresis after exposure to lowintensity red (Figure 1 top) and infrared (Figure 1 bottom) lasers at various fluences and incubated with $T_{4}$ endonuclease V. Data in this figure indicate that exposure to lasers did not significantly $(P>0.05)$ induce quantitative or qualitative alterations in the electrophoretic profile of plasmid DNA as was determined in preliminary experiments (data not shown). The electrophoretic profiles of plasmids exposed to red or infrared lasers and incubated with $T_{4}$ endonuclease $V$ were not significantly $(P>0.05)$ different from profiles of plasmids not incubated with $T_{4}$ endonuclease $\mathrm{V}$.

To determine whether the power of the laser beam influenced the DNA repair enzyme activity, plasmids were exposed to lasers at $100 \mathrm{~J} / \mathrm{cm}^{2}$ in continuous wave emission mode at various powers. No significant $(P>0.05)$ quantitative or qualitative alterations in the electrophoretic profiles of plasmids were observed after exposure to either red or infrared lasers. Similar results were obtained when plasmids were exposed to lasers and incubated with $\mathrm{T}_{4}$ endonuclease $\mathrm{V}$ (Figure 2).

Significant alterations were not seen in the electrophoretic profiles of plasmids exposed to red or infrared lasers, or in plasmids exposed to lasers and incubated with the enzyme in different emission modes (continuous wave or pulsed) with a fluence of $100 \mathrm{~J} / \mathrm{cm}^{2}$ and power of $100 \mathrm{~mW}$ (Figure 3).

\section{Bacterial filamentation in E. coli cultures exposed to red and infrared lasers}

Figure 4 shows representative images of cells from E. coli AB1157 cultures in exponential growth phase (Figure 4A) and analysis of induction of bacterial filaments (Figure 4B). Table 2 shows the percentages of bacterial filaments in cultures of $E$. coli AB1157 and AB1886 exposed to low-intensity red and infrared lasers at different fluences, powers, and emission modes. Laser exposure significantly $(P<0.05)$ increased the percentage of bacterial filaments in both $E$. coli AB1157 and AB1886 cultures. Filamentation induction was fluence-dependent in $E$. coli $A B 1157$ for the infrared laser and inversely fluence-dependent in $E$. coli $\mathrm{AB} 1886$ for the red laser. Also, at the lowest powers, a significant $(P<0.05)$ increase in the percentage of bacterial filaments occurred in E. coli AB1157 cultures exposed to lasers at $100 \mathrm{~J} / \mathrm{cm}^{2}$ in the continuous wave emission mode. However, at low power $(30 \mathrm{~mW})$, neither the red nor the infrared laser significantly increased the percentage of bacterial filaments in $E$. coli AB1886 cultures $(P>0.05)$. Lasers significantly $(P<0.05)$ increased the percentage of bacterial filaments in E. coli AB1157 and AB1886 cultures in both continuous wave and pulsed emission modes. 

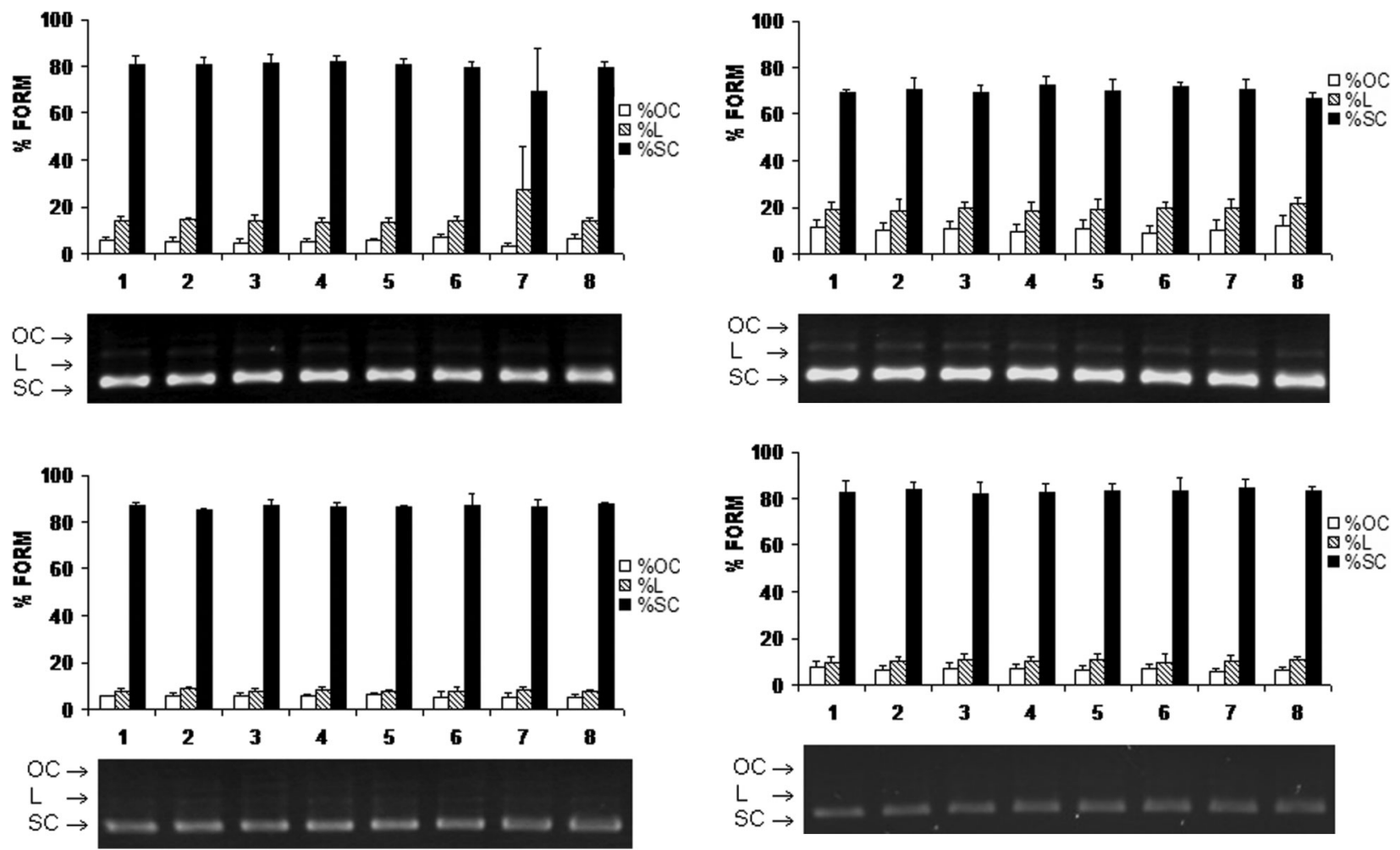

Figure 2. Percentages of bacterial plasmid forms and photographs of agarose gels after electrophoresis of plasmid pUC19 exposed to red lasers (top) and to infrared lasers (bottom) at different powers, $100 \mathrm{~J} / \mathrm{cm}^{2}$ in continuous wave emission mode, and incubated with T4 endonuclease V. Top: lane 1, pUC19; lane 2, pUC19+T4 endonuclease $\mathrm{V}$; lane 3, pUC19+red laser $30 \mathrm{~mW}$; lane 4, pUC19+red laser $30 \mathrm{~mW}+\mathrm{T} 4$ endonuclease $\mathrm{V}$; lane 5, pUC19+red laser $50 \mathrm{~mW}$; lane 6, pUC19+red laser $50 \mathrm{~mW}+\mathrm{T} 4$ endonuclease V; lane 7, pUC19 + red laser $100 \mathrm{~mW}$; lane 8, pUC19 + red laser $100 \mathrm{~mW}+\mathrm{T} 4$ endonuclease $\mathrm{V}$. Bottom: lane 1, pUC19; lane 2, pUC19+T4 endonuclease V; lane 3, pUC19+infrared laser $30 \mathrm{~mW}$; lane 4, pUC19+infrared laser $30 \mathrm{~mW}+\mathrm{T} 4$ endonuclease $\mathrm{V}$; lane 5 , pUC19+infrared laser $50 \mathrm{~mW}$; lane 6, pUC19+infrared laser $50 \mathrm{~mW}+\mathrm{T} 4$ endonuclease V; lane 7, pUC19 + infrared laser 100 mW; lane 8, pUC19+ infrared laser $100 \mathrm{~mW}+\mathrm{T} 4$ endonuclease $\mathrm{V}$. Data are reported as the means $\pm S D$ for $n=3$ independent experiments. OC: open circle, L: linear, SC: supercoiled.

However, this effect was not dependent on pulse frequency, except for the red laser in $E$. coli $\mathrm{AB} 1886$.

\section{Evaluation of morphology of $E$. coli cells exposed to red and infrared lasers}

Area and perimeter of $E$. coli AB1157 and AB1886 cells were evaluated following exposure to red and infrared lasers at different fluences, powers, and emission modes (Tables 3 and 4). At $100 \mathrm{~mW}$ in the continuous wave emission mode, red laser exposure significantly $(P<0.05)$ reduced $E$. coli AB1157 cell area at the highest fluence evaluated (100 $\mathrm{J} / \mathrm{cm}^{2}$ ). On the other hand, the infrared laser significantly

Figure 3. Percentages of bacterial plasmid forms and photographs of agarose gels after electrophoresis of plasmid pUC19 exposed to red lasers (top) and to infrared lasers (bottom), at different frequencies, $100 \mathrm{~mW}$ and $100 \mathrm{~J} / \mathrm{cm}^{2}$, and incubated with T4 endonuclease V. Top: lane 1, pUC19; lane 2, pUC19+T4 endonuclease V; lane 3, pUC19+red laser 10 pps; lane 4, pUC19+red laser 10 pps + T4 endonuclease V; lane 5, pUC19 + red laser 30 pps; lane 6, pUC19+red laser 30 pps + T4 endonuclease $\mathrm{V}$; lane 7 , pUC19+red laser $100 \mathrm{pps}$; lane 8 , pUC19 + red laser 100 pps + T4 endonuclease V. Bottom: lane 1, pUC19; lane 2, pUC19+T4 endonuclease V; lane 3, pUC19+ infrared laser 10 pps; lane 4, pUC19+infrared laser 10 pps + T4 endonuclease $\mathrm{V}$; lane 5 , pUC19+infrared laser 30 pps; lane 6 , pUC19+infrared laser 30 pps +T4 endonuclease V; lane 7, pUC19+infrared laser $100 \mathrm{pps}$; lane 8, pUC19+infrared laser $100 \mathrm{pps}+\mathrm{T} 4$ endonuclease V. Data are reported as the means $\pm S D$ for $n=3$ independent experiments. OC: open circle, $L$ : linear, SC: supercoiled.

$(P<0.05)$ increased both area and perimeter of those bacterial cells. When the cells were exposed to the red laser at lower powers (30 and $50 \mathrm{~mW})$ at $100 \mathrm{~J} / \mathrm{cm}^{2}$ in continuous wave emission, no significant $(P>0.05)$ alteration in area and perimeter occurred. However, under the same conditions, the infrared laser induced increases in both area and perimeter of $E$. coli AB1157 cells. Similar to the results obtained at lower powers, the red laser in pulsed emission mode, $100 \mathrm{~mW}$, and $100 \mathrm{~J} / \mathrm{cm}^{2}$ did not induce area and perimeter changes of $E$. coli $\mathrm{AB} 1157$ cells, but the infrared laser induced significant $(P<0.05)$ increases of both morphological parameters. Area and perimeter were also 


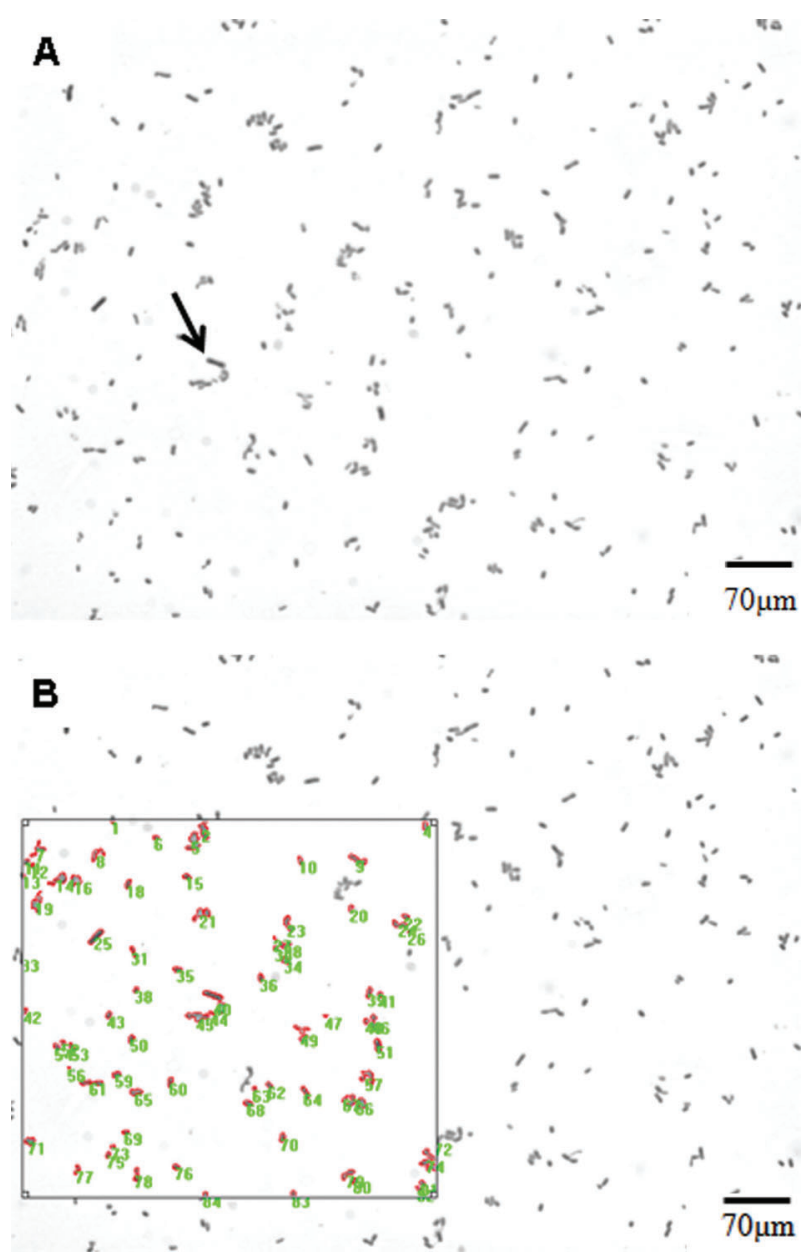

Figure 4. Representative bacterial filamentation images from AB1157 cultures in exponential growth phase. $A$, The arrow indicates a bacterial filament; $B$, Same image demonstrating how image analysis was performed. A bacterial filament was considered to have an area 2.5 times larger than the mean bacterial cell.

evaluated in E. coli AB1886 following exposure to both red and infrared lasers (Table 4) under the same conditions evaluated for $E$. coli AB1157 cells. No significant changes $(P>0.05)$ in either morphological parameter were observed in E. coli AB1886 cells following exposure to either red or infrared lasers at $100 \mathrm{~mW}$ in continuous wave mode emission or at any of the tested fluences. However, laser exposure at lower powers (30 and $50 \mathrm{~mW}$ ), $100 \mathrm{~J} / \mathrm{cm}^{2}$, and continuous wave emission, significantly $(P<0.05)$ decreased area and perimeter of these cells. In pulsed emission mode, both lasers induced a decrease of morphological parameters, except for the red laser at 100 pps.

\section{Discussion}

Some studies have suggested that exposure to lowintensity laser light induces cellular alterations causing increase in resistance to nonionizing (27), ionizing (28), and oxidative chemical compounds (25). Those studies prompted evaluation of the effects of lasers on DNA molecules $(18-20,29)$. Our study results show that lowintensity red lasers at fluences, powers, and emission modes used in clinical protocols were not lethal to $E$. coli cells proficient in DNA repair (strain AB1157, Table 1). Instead, survival fractions were increased at the lowest power $(30 \mathrm{~mW})$, suggesting a power-dependent biological effect (biostimulation). Previous studies demonstrated a biostimulatory effect in prokaryote (10) and eukaryote (30) cells. Recently, we observed this effect in cell cultures proficient in DNA repair mechanisms, but not in an E. coli strain deficient in repair of oxidative DNA lesions (20). No studies have demonstrated biostimulation that was dependent on laser beam power. Here, survival of uvrA-deficient $E$. coli cells was decreased by red lasers at all evaluated powers, but only at the highest fluence $\left(100 \mathrm{~J} / \mathrm{cm}^{2}\right)$ and in the continuous wave emission mode. These results agree with previously reported data, suggesting that the biological effects of low-intensity lasers are frequency-dependent (25). Moreover, these cells were sensitive to infrared lasers at lower fluences, but only at the highest power (100 mW) and in the continuous wave emission mode. Despite the importance of this biological aspect, our study describes, for the first time, how cells deficient in the nucleotide excision repair of DNA damage are sensitive to low-intensity laser radiation. These results support the hypothesis that laserinduced biological effects are dependent on DNA repair mechanisms (17).

$\mathrm{T}_{4}$ endonuclease $\mathrm{V}$ is a highly specific glycosylase that cleaves the glycosydic bond of cyclobutane pyrimidine dimers induced by ultraviolet radiation and possesses a concomitant DNA apurinic or apyrimidinic (AP) lyase activity at basic sites generated by glycosylase action (31). Due to these properties, $\mathrm{T}_{4}$ endonuclease $\mathrm{V}$ protects patients with xeroderma pigmentosum against skin cancer (32). Plasmid DNA exposed to low-intensity red and infrared lasers did not show any alterations in electrophoretic profile in agarose gels, suggesting absence of detectable singleor double-strand DNA breaks, as previous studies have demonstrated $(19,20)$. In addition, the plasmids did not show any alteration in their electrophoretic profile after incubation with $\mathrm{T}_{4}$ endonuclease $\mathrm{V}$, suggesting that red and infrared laser lights did not induce DNA lesions targeted by this enzyme, at least under the laser irradiation conditions used in this study.

Whether significant laser light energy is directly or indirectly absorbed by DNA molecules remains controversial. For ultraviolet A radiation $(320-400 \mathrm{~nm})$, it has been suggested that DNA lesions are induced by direct (33) or indirect mechanisms (34). An unidentified chromophore might be involved in the indirect mechanism for absorbing the ultraviolet radiation energy and subsequently transferring it to DNA molecules (34). A similar indirect mechanism might be related to absorption of laser light energy by cells and its 
Table 2. Percentages of bacterial filaments from E. coli cultures exposed to red and infrared lasers at different fluences, powers, and emission modes.

\begin{tabular}{|c|c|c|c|c|}
\hline & \multicolumn{2}{|c|}{ AB1157 } & \multicolumn{2}{|c|}{ AB1886 } \\
\hline & Red & Infrared & Red & Infrared \\
\hline \multicolumn{5}{|c|}{ Fluence $\left(\mathrm{J} / \mathrm{cm}^{2}\right)$} \\
\hline Control & $4.0 \pm 0.25$ & $4.0 \pm 0.25$ & $5.3 \pm 0.24$ & $5.3 \pm 0.24$ \\
\hline 25 & $12.0 \pm 1.33^{*}$ & $8.4 \pm 0.19^{*}$ & $28.3 \pm 2.26^{*}$ & $9.0 \pm 0.74^{*}$ \\
\hline 50 & $9.6 \pm 0.58^{*}$ & $9.0 \pm 0.13^{*}$ & $20.7 \pm 2.13^{*}$ & $14.7 \pm 1.39^{*}$ \\
\hline 100 & $9.0 \pm 0.33^{*}$ & $26.3 \pm 1.45^{\star}$ & $9.3 \pm 1.70^{*}$ & $11.0 \pm 1.35^{*}$ \\
\hline \multicolumn{5}{|l|}{ Power (mW) } \\
\hline 30 & $13.0 \pm 1.49^{*}$ & $33.1 \pm 1.59^{\star}$ & $4.3 \pm 0.57$ & $5.3 \pm 0.22$ \\
\hline 50 & $11.3 \pm 1.21^{*}$ & $29.2 \pm 1.78^{*}$ & $6.7 \pm 0.25^{*}$ & $7.3 \pm 0.54^{*}$ \\
\hline 100 & $9.0 \pm 0.33^{*}$ & $26.3 \pm 1.45^{*}$ & $9.3 \pm 1.70^{*}$ & $11.0 \pm 1.35^{*}$ \\
\hline \multicolumn{5}{|c|}{ Frequency (pps) } \\
\hline Continuous & $9.0 \pm 0.33^{*}$ & $26.3 \pm 1.45^{\star}$ & $9.3 \pm 1.70^{*}$ & $11.0 \pm 1.35^{*}$ \\
\hline 10 & $14.1 \pm 1.27^{*}$ & $25.0 \pm 1.57^{*}$ & $7.3 \pm 0.42^{*}$ & $10.4 \pm 1.09^{*}$ \\
\hline 100 & $8.7 \pm 0.73^{*}$ & $26.3 \pm 1.48^{*}$ & $19.7 \pm 1.67^{*}$ & $8.4 \pm 0.71^{*}$ \\
\hline
\end{tabular}

Data are reported as the means \pm SD. pps: pulses per second. ${ }^{*} \mathrm{P}<0.05$ vs control group not exposed to lasers (ANOVA).

effects on the DNA molecule. In fact, cytochrome $C$ in eukaryotic and cytochrome BD in prokaryotic cells are chromophores for red and infrared laser light (11). This could explain the lack of change in the electrophoretic profile of plasmids incubated with $\mathrm{T}_{4}$ endonuclease $\mathrm{V}$, even though $E$. coli AB1886 cultures were sensitive to red and infrared lasers.

Previous studies have demonstrated induction of filamentation in $E$. coli cells exposed to low-intensity lasers (18-20). Wild-type E. coli cells (strain AB1157) exhibited a filamentous phenotype after exposure to both red and infrared lasers, and primarily with infrared lasers at the highest fluence $\left(100 \mathrm{~J} / \mathrm{cm}^{2}\right)$. Interestingly, laserinduced filamentation was slightly greater at lower powers, but was similar for the continuous wave and pulsed emission modes, except at 10 pps for the red laser. In this study, the filamentous phenotype was described for the first time in a strain of $E$. coli deficient in nucleotide excision repair (strain AB1886, Table 2). Except for red laser exposures at low fluences $\left(25\right.$ and $\left.50 \mathrm{~J} / \mathrm{cm}^{2}\right), E$. coli AB1886 cells exhibited the lowest percentages of

Table 3. Area and perimeter of $E$. coli $\mathrm{AB} 1157$ cells exposed to red and infrared lasers at different fluences, powers, and emission modes.

\begin{tabular}{|c|c|c|c|c|}
\hline & \multicolumn{2}{|c|}{ Area $\left(\mu \mathrm{m}^{2}\right)$} & \multicolumn{2}{|c|}{ Perimeter $(\mu \mathrm{m})$} \\
\hline & Red & Infrared & Red & Infrared \\
\hline \multicolumn{5}{|c|}{ Fluence $\left(\mathrm{J} / \mathrm{cm}^{2}\right)$} \\
\hline Control & $1.8 \pm 0.59$ & $1.8 \pm 0.59$ & $5.9 \pm 1.24$ & $5.9 \pm 1.24$ \\
\hline 25 & $1.9 \pm 0.66$ & $1.8 \pm 0.60$ & $6.6 \pm 1.51$ & $6.2 \pm 1.31$ \\
\hline 50 & $1.7 \pm 0.51$ & $2.2 \pm 0.68^{*}$ & $6.1 \pm 1.26$ & $6.4 \pm 1.25^{\star}$ \\
\hline 100 & $1.5 \pm 0.55^{*}$ & $2.5 \pm 0.98^{*}$ & $5.7 \pm 1.31$ & $7.1 \pm 1.74^{*}$ \\
\hline \multicolumn{5}{|l|}{ Power (mW) } \\
\hline 30 & $1.8 \pm 0.73$ & $2.7 \pm 0.90^{*}$ & $6.4 \pm 1.57$ & $7.3 \pm 1.50^{*}$ \\
\hline 50 & $1.8 \pm 0.63$ & $2.2 \pm 0.69^{*}$ & $6.3 \pm 1.48$ & $6.5 \pm 1.53^{*}$ \\
\hline 100 & $1.5 \pm 0.55^{\star}$ & $2.5 \pm 0.98^{*}$ & $5.7 \pm 1.31$ & $7.1 \pm 1.74^{*}$ \\
\hline \multicolumn{5}{|c|}{ Frequency (pps) } \\
\hline Continuous & $1.5 \pm 0.55^{*}$ & $2.5 \pm 0.98^{*}$ & $5.7 \pm 1.31$ & $7.1 \pm 1.74^{*}$ \\
\hline 10 & $1.7 \pm 0.62$ & $2.7 \pm 0.90^{*}$ & $6.3 \pm 1.48$ & $7.3 \pm 1.50^{*}$ \\
\hline 100 & $1.7 \pm 0.61$ & $2.2 \pm 0.69^{*}$ & $6.0 \pm 1.36$ & $6.5 \pm 1.53$ \\
\hline
\end{tabular}

Data are reported as the means $\pm S D$. pps: pulses per second. ${ }^{*} P<0.05$ vs control group not exposed to lasers (ANOVA). 
Table 4. Area and perimeter of $E$. coli AB1886 cells exposed to red and infrared lasers at different fluences, powers, and emission modes.

\begin{tabular}{lccccc}
\hline & \multicolumn{2}{c}{ Area $\left(\mu \mathrm{m}^{2}\right)$} & & \multicolumn{2}{c}{ Perimeter $(\mu \mathrm{m})$} \\
\cline { 2 - 3 } \cline { 5 - 6 } & Red & Infrared & & Red & Infrared \\
\hline Fluence $\left(\mathrm{J} / \mathrm{cm}^{2}\right)$ & & & & & \\
$\quad$ Control & $2.0 \pm 0.75$ & $2.0 \pm 0.75$ & & $6.6 \pm 1.76$ & $6.6 \pm 1.76$ \\
25 & $2.1 \pm 0.71$ & $1.8 \pm 0.62$ & $6.8 \pm 1.62$ & $6.3 \pm 1.46$ \\
50 & $2.1 \pm 0.78$ & $1.9 \pm 0.59$ & $6.7 \pm 1.59$ & $6.5 \pm 1.30$ \\
100 & $2.0 \pm 0.57$ & $2.0 \pm 0.58$ & $6.5 \pm 1.43$ & $6.7 \pm 1.28$ \\
Power (mW) & & & & & \\
30 & $1.8 \pm 0.42^{*}$ & $1.7 \pm 0.48^{*}$ & & $5.9 \pm 0.88^{*}$ & $6.0 \pm 1.00^{*}$ \\
50 & $1.5 \pm 0.53^{*}$ & $1.8 \pm 0.63^{*}$ & $5.6 \pm 1.39^{*}$ & $6.0 \pm 1.30^{*}$ \\
100 & $2.0 \pm 0.57$ & $2.0 \pm 0.58$ & & $6.5 \pm 1.43$ & $6.7 \pm 1.28$ \\
Frequency (pps) & & & & & \\
$\quad$ Continuous & $2.0 \pm 0.57$ & $2.0 \pm 0.58$ & $6.5 \pm 1.43$ & $6.7 \pm 1.28$ \\
10 & $1.6 \pm 0.81^{*}$ & $1.7 \pm 0.88^{*}$ & $6.1 \pm 2.33^{*}$ & $6.3 \pm 1.09^{*}$ \\
100 & $2.0 \pm 0.55$ & $1.8 \pm 0.91^{*}$ & $6.5 \pm 1.76$ & $6.0 \pm 1.93^{*}$ \\
\hline
\end{tabular}

Data are reported as the means $\pm \mathrm{SD}$. pps: pulses per second. ${ }^{*} \mathrm{P}<0.05$ vs control group not exposed to lasers (ANOVA).

bacterial filaments. This can be attributed to increased cellular inactivation at those fluences (Table 1), preventing more cells from presenting a filamentous phenotype. In fact, cellular filamentation is a strategy to restore normal internal conditions, mainly DNA lesions, in order to survive injury (24). The appearance of red and infrared laserinduced filamentous phenotypes was power-, but not frequency-dependent, occurring after exposure to lasers in the continuous wave and pulsed emission modes.

The filamentation assay performed in this study showed that low-intensity red and infrared lasers induced SOS responses in bacterial cells. However, the assay permitted evaluation of the percentage of bacterial filaments induced by laser exposure but not the morphology of cells that did not present that phenotype. Computer software has been used to perform measurements of morphological parameters (35). In fact, data in Table 2 show that bacterial filaments occurred in fewer than $30 \%$ of both E. coli AB1157 and AB1886 cultures exposed to lasers.

Cell area and perimeter were measured to evaluate the morphology of bacterial cells that did not exhibit a filamentous phenotype. Red and infrared laser light induced different alterations in E. coli AB1157 cell area and perimeter (Table 3). Red laser exposure decreased cell area at the highest fluence $\left(100 \mathrm{~J} / \mathrm{cm}^{2}\right)$ and power $(100 \mathrm{~mW})$ in the continuous wave emission mode. Infrared laser exposure increased both morphological parameters at $50 \mathrm{~J} / \mathrm{cm}^{2}$, at the lower powers, and in both the continuous wave and pulsed emission modes. These results demonstrate that the wavelength of laser light acts to cause changes in cell morphology. In E. coli AB1886 cells, red and infrared lasers at the highest power in the continuous wave mode did not alter cell morphology (Table 4). However, at lower powers and in the pulsed emission mode, both red and infrared lasers altered the area and perimeter of cells, but both lasers decreased those parameters. These results reinforce the suggestion that biological effects induced by low-intensity lasers depend on physical parameters (power and emission mode) as well as the presence of DNA repair mechanisms (17). On the other hand, data from morphological analysis indicate that low-level laser light can alter the function of membrane ion channels. Changes in morphological parameters such as area and perimeter are associated with changes in the function of those membrane proteins (36). In fact, He-Ne lasers operating at $632.8 \mathrm{~nm}$ increase or decrease the amplitude of membrane potentials dependent on slow potassium currents in a fluencedependent way (37). Low pulse energy neodymium: yttrium-aluminum-garnet (Nd:YAG) laser light increases intracellular $\mathrm{Ca}^{2+}$ concentration in osteoblasts through the activation of TRPC1 ion channels (38). Membrane conductance through voltage-gated $\mathrm{K}^{+}, \mathrm{BK}$, and Kir channels and $\mathrm{T}$ - and L-type $\mathrm{Ca}^{2+}$ channels is increased following red laser exposure at low fluence and power (39). Also, infrared lasers at $810 \mathrm{~nm}$ raise mitochondrial membrane potential and reduce intracellular $\mathrm{Ca}^{2+}$ concentration (40).

Although our research was performed with bacterial cells, low-intensity lasers at fluences used in clinical protocols could induce biological effects depending on cellular genetic characteristics, such as functional DNA repair by the nucleotide excision pathway.

\section{Acknowledgments}

This research was supported by FAPERJ (APQ1-E\#26/111.794/2012), FAPEMIG (APQ \#00432/13), and CNPq (\#474405/2013-3). 


\section{References}

1. Raber-Durlacher JE, von Bultzingslowen I, Logan RM, Bowen J, Al-Azri AR, Everaus $\mathrm{H}$, et al. Systematic review of cytokines and growth factors for the management of oral mucositis in cancer patients. Support Care Cancer 2013; 21: 343-355, doi: 10.1007/s00520-012-1594-5.

2. McGowan D. Chemotherapy-induced oral dysfunction: a literature review. Br J Nurs 2008; 17: 1422-1426.

3. Georgiou M, Patapatiou G, Domoxoudis S, Pistevou-Gompaki K, Papanikolaou A. Oral Mucositis: understanding the pathology and management. Hippokratia 2012; 16: 215-216.

4. Migliorati C, Hewson I, Lalla RV, Antunes HS, Estilo CL, Hodgson B, et al. Systematic review of laser and other light therapy for the management of oral mucositis in cancer patients. Support Care Cancer 2013; 21: 333-341, doi: 10.1007/ s00520-012-1605-6.

5. Kim YG. Laser mediated production of reactive oxygen and nitrogen species; implications for therapy. Free Radic Res 2002; 36: 1243-1250, doi: 10.1080/1071576021000028389.

6. Karu TI. Mitochondrial signaling in mammalian cells activated by red and near-IR radiation. Photochem Photobiol 2008; 84: 1091-1099, doi: 10.1111/j.1751-1097.2008.00394.x.

7. Karu T. Mitochondrial mechanisms of photobiomodulation in context of new data about multiple roles of ATP. Photomed Laser Surg 2010; 28: 159-160, doi: 10.1089/pho.2010.2789.

8. Pereira AN, Eduardo CP, Matson E, Marques MM. Effect of low-power laser irradiation on cell growth and procollagen synthesis of cultured fibroblasts. Lasers Surg Med 2002; 31: 263-267.

9. De Souza TO, Martins MA, Bussadori SK, Fernandes KP, Tanji EY, Mesquita-Ferrari RA, et al. Clinical evaluation of low-level laser treatment for recurring aphthous stomatitis. Photomed Laser Surg 2010; 28 (Suppl 2): S85-S88, doi: 10.1089/pho.2009.2661.

10. Karu T. Primary and secondary mechanisms of action of visible to near-IR radiation on cells. J Photochem Photobiol $B$ 1999; 49: 1-17, doi: 10.1016/S1011-1344(98)00219-X.

11. Karu T, Pyatibrat L. Gene expression under laser and lightemitting diodes radiation for modulation of cell adhesion: Possible applications for biotechnology. IUBMB Life 2011; 63: 747-753.

12. Migliario M, Pittarella P, Fanuli M, Rizzi M, Reno F. Laserinduced osteoblast proliferation is mediated by ROS production. Lasers Med Sci 2014; 29: 1463-1467, doi: 10.1007/ s10103-014-1556-X

13. Hawkins $\mathrm{DH}$, Abrahamse $\mathrm{H}$. The role of laser fluence in cell viability, proliferation, and membrane integrity of wounded human skin fibroblasts following helium-neon laser irradiation. Lasers Surg Med 2006; 38: 74-83.

14. Godon C, Cordelieres FP, Biard D, Giocanti N, MegninChanet $F$, Hall J, et al. PARP inhibition versus PARP-1 silencing: different outcomes in terms of single-strand break repair and radiation susceptibility. Nucleic Acids Res 2008; 36: 4454-4464, doi: 10.1093/nar/gkn403.

15. Mbene AB, Houreld NN, Abrahamse H. DNA damage after phototherapy in wounded fibroblast cells irradiated with $16 \mathrm{~J} / \mathrm{cm}(2)$. J Photochem Photobiol B 2009; 94: 131-137, doi: 10.1016/j.jphotobiol.2008.11.002.

16. Kohli R, Gupta PK. Irradiance dependence of the He-Ne laser-induced protection against UVC radiation in $E$. coli strains. J Photochem Photobiol B 2003; 69: 161-167, doi: 10.1016/S1011-1344(03)00018-6.

17. Fonseca AS, Geller M, Bernardo Filho M, Valenca SS, de Paoli F. Low-level infrared laser effect on plasmid DNA. Lasers Med Sci 2012; 27: 121-130, doi: 10.1007/s10103011-0905-2.

18. da Fonseca Ade S, Presta GA, Geller M, de Paoli F, Valenca SS. Low-intensity infrared laser increases plasma proteins and induces oxidative stress in vitro. Lasers Med Sci 2012; 27: 211-217, doi: 10.1007/s10103-011-0945-7.

19. da Silva Marciano R, da Silva Sergio LP, Polignano GA, Presta GA, Guimaraes OR, Geller M, et al. Laser for treatment of aphthous ulcers on bacteria cultures and DNA. Photochem Photobiol Sci 2012; 11: 1476-1483, doi: 10.1039/ c2pp25027f.

20. Canuto KS, Sergio LPS, Marciano RS, Guimarães OR, Polignano GAC, Geller M, et al. DNA repair in bacterial cultures and plasmid DNA exposed to infrared laser for treatment of pain. Laser Phys Lett 2013; 10: 065606, doi: 10.1088/1612-2011/10/6/065606.

21. Koch WH, Woodgate R. The SOS response. In: Nickoloff JA, Hoekstra MF (Editors), DNA damage and repair. Vol. I: DNA repair in procaryotes and lower eukaryotes. New Jersey: Humana Press; 1998. p 107-134.

22. Grzesiuk E, Gozdek A, Tudek B. Contribution of E. coli AlkA, TagA glycosylases and UvrABC-excinuclease in MMS mutagenesis. Mutat Res 2001; 480-481: 77-84, doi: 10.1016/ S0027-5107(01)00171-3.

23. Slayden RA, Knudson DL, Belisle JT. Identification of cell cycle regulators in Mycobacterium tuberculosis by inhibition of septum formation and global transcriptional analysis. Microbiology 2006; 152: 1789-1797, doi: 10.1099/mic.0.2 8762-0.

24. Modenutti B, Balseiro E, Corno G, Callieri C, Bertoni R, Caravati $\mathrm{E}$. Ultraviolet radiation induces filamentation in bacterial assemblages from North Andean Patagonian lakes. Photochem Photobiol 2010; 86: 871-881, doi: 10.1111/ j.1751-1097.2010.00758.x.

25. Fonseca AS, Moreira TO, Paixao DL, Farias FM, Guimaraes OR, de Paoli S, et al. Effect of laser therapy on DNA damage. Lasers Surg Med 2010; 42: 481-488, doi: 10.1002/lsm.20921.

26. Cappuccino JG, Sherman N. Microbiology: a laboratory manual. San Francisco: Benjamin Cummings Science Publishing; 1999.

27. Kohli R, Gupta PK, Dube A. Helium-neon laser preirradiation induces protection against UVC radiation in wild-type $E$. coli strain K12AB1157. Radiat Res 2000; 153: 181-185, doi: 10.1667/0033-7587(2000)153[0181:HNLPIP]2.0.CO;2.

28. Karu T, Pyatibrat L, Kalendo G. Irradiation with He-Ne laser can influence the cytotoxic response of HeLa cells to ionizing radiation. Int J Radiat Biol 1994; 65: 691-697.

29. da Silva Sergio LP, da Silva Marciano R, Castanheira Polignano GA, Guimarães OR, Paoli $F$, et al. Evaluation of DNA damage induced by therapeutic low-level red laser. J Clin Exp Dermatol Res 2012; 3: 166.

30. Fedoseyeva GE, Karu TI, Lyapunova TS, Pomoshnikova NA, Meissel MN. The activation of yeast metabolism with $\mathrm{He}-\mathrm{Ne}$ laser irradiation. I. Protein synthesis in various cultures. Lasers Life Sci 1988; 2: 137. 
31. McCullough AK, Dodson ML, Scharer OD, Lloyd RS. The role of base flipping in damage recognition and catalysis by T4 endonuclease V. J Biol Chem 1997; 272: 27210-27217.

32. Emanuel P, Scheinfeld N. A review of DNA repair and possible DNA-repair adjuvants and selected natural antioxidants. Dermatol Online J 2007; 13: 10.

33. Kuluncsics Z, Perdiz D, Brulay E, Muel B, Sage E. Wavelength dependence of ultraviolet-induced DNA damage distribution: involvement of direct or indirect mechanisms and possible artefacts. J Photochem Photobiol B 1999; 49: 71-80, doi: 10.1016/S1011-1344(99)00034-2.

34. Mouret S, Baudouin C, Charveron M, Favier A, Cadet J, Douki T. Cyclobutane pyrimidine dimers are predominant DNA lesions in whole human skin exposed to UVA radiation. Proc Natl Acad Sci U S A 2006; 103: 13765-13770, doi: $10.1073 /$ pnas. 0604213103 .

35. Hua R, Liu L, Li C, Chen L. Evaluation of the effects of photodynamic therapy on chronic central serous chorioretinopathy based on the mean choroidal thickness and the lumen area of abnormal choroidal vessels. Photodiagnosis Photodyn Ther 2014; 11: 519-525, doi: 10.1016/j.pdpdt.2014.07.005.
36. Hoffmann EK, Holm NB, Lambert IH. Functions of volumesensitive and calcium-activated chloride channels. IUBMB Life 2014; 66: 257-267, doi: 10.1002/iub.1266.

37. Ignatov YD, Vislobokov Al, Vlasov TD, Kolpakova ME, Mel'nikov KN, Petrishchev IN. Effects of helium-neon laser irradiation and local anesthetics on potassium channels in pond snail neurons. Neurosci Behav Physiol 2005; 35: 871-875, doi: 10.1007/s11055-005-0137-7.

38. Chellini F, Sassoli C, Nosi D, Deledda C, Tonelli P, ZecchiOrlandini $S$, et al. Low pulse energy Nd:YAG laser irradiation exerts a biostimulative effect on different cells of the oral microenvironment: "an in vitro study". Lasers Surg Med 2010; 42: 527-539, doi: 10.1002/lsm.20861.

39. Giannelli M, Chellini F, Sassoli C, Francini F, Pini A, Squecco R, et al. Photoactivation of bone marrow mesenchymal stromal cells with diode laser: effects and mechanisms of action. J Cell Physiol 2013; 228: 172-181, doi: 10.1002/ jcp.24119.

40. Huang YY, Nagata K, Tedford CE, Hamblin MR. Low-level laser therapy $(810 \mathrm{~nm})$ protects primary cortical neurons against excitotoxicity in vitro. J Biophotonics 2014; 7: 656-664, doi: $10.1002 /$ jbio.201300125. 